\title{
Pregnant Bodies
}

\section{Norwegian Female Employees in Global Working Life}

\author{
Hege Eggen Børve
}

NORWEGIAN UNIVERSITY OF SCIENCE AND TECHNOLOGY

ABSTRACT This article examines the impact that the interplay between workplace, the welfare state and global working life has on female workers when they become pregnant. By focusing on two highly educated Norwegian female workers, it explores how this change process takes place in two companies operating in the global market located in different countries: Norway and the US. Pregnancy contributes to transforming the neutralized bodiless female worker into an embodied worker with gender. The female workers' experiences and negotiations represent forms of global action on local stages. This is illustrated by four processes: 'married to work', 'pregnant and still married to work', 'negotiating separation from work' and 'excluding mothering'. The findings indicate the significance of taking welfare state and workplace policy approaches into consideration in studies of global effects on employees.

KEY WORDS body $\bullet$ gender $\bullet$ global $\bullet$ welfare state $\bullet$ workplace culture

\section{INTRODUCTION}

Globalization $^{1}$ is one of the major concepts in discussions about the change processes taking place in working life. It is often described as a multidimensional process (Hirst and Thompson, 1996), involving changes in economic, social, political, cultural and demographic processes (Kearney, 1995). Globalization introduces new places and cross-border arenas that are related to entities like transnational and multinational corporations; corporations operating across nations. These industries can be defined as hightech workplaces with strong gender divisions of labour (Wajcman, 1999). Increasing globalization implies that a growing number of employees have

European Journal of Women's Studies Copyright (c) 2007 SAGE Publications (Los Angeles, London, New Delhi and Singapore), 1350-5068 Vol. 14(4): 311-326; http:/ / ejw.sagepub.com DOI: 10.1177/1350506807081878 
found work in multinational corporations. These jobs often require long working hours, intense commitment and place demands on how the workers use their time (Sassen, 2002).

Studies of Norwegian male employees show that being part of a global working life forces men to give priority to work before family (Kvande, 2005). Even though they may wish to give priority to active fathering, they are disciplined into becoming total-commitment workers. While Kvande's (2005) study concentrates on the consequences of the development of so-called global business masculinities for male employees, this article concentrates on female employees. Globalization and women have been the focus in many studies, as for instance female managers (Adler, 1986, 1994), women and technology (Mitter and Rowbotham, 1995), nannies, maids and sex workers (Ehrenreich and Hochschild, 2002; Sassen, 2000). Impacts of globalization on female employees during pregnancy are less prevalent.

In this article I take as my point of departure case studies of Norwegian female employees working in global companies. What happens when female employees working in a global setting become pregnant? How are they affected by the interplay between the global and the local? In particular I intend to elaborate on the impact of the global and the local and how this affects women's experiences and negotiation during their pregnancy and early stages of parenthood.

\section{GLOBALIZATION AND FLEXIBLE WORKING CULTURES}

Time is crucial to understanding change in post-industrial societies (Ellingsæter, 1999b). One major change process taking place is the move from standardized working hours to a regime where the distinction between work and leisure is under pressure. In contrast to the industrial time regime, there is an increase in differentiation and flexibility of working hours (Hewitt, 1993). At company level, this occurs through the development of new time cultures in work organizations (Epstein et al., 1999; Hochschild, 2001). Richard Sennett (1998) describes how employees in the new time regime experience the increasing differentiation and flexibility of working hours, where the result often is that employees spend increasingly more time at work and less time with their families. This applies in particular to 'high-commitment' knowledge companies where knowledge and competence are individualized and the formal contract that regulates working hours thus is being replaced by moral obligations and time norms expecting total commitment.

Today there are signs that the working week is expanding in parts of the western economy (Fagen, 2002), particularly in the managerial and professional grades (Golden and Figart, 2000). The US has the longest 
working week in the world (Hochschild, 2001), while Britain has one of the longest in Europe. The tendency to stretch working time beyond normal working hours and to work unpaid overtime is also becoming more common in Norway (Andersen, 2003). There is variation within branches and countries so that the extent to which this is a general development in the western world is open to discussion. However, these so-called boundless time cultures put pressure on normal working hours.

Women who want to succeed in a professional or managerial position face strong pressures at work (Hochschild, 2002). Many women have succeeded by turning over the care of their children and home to women from the Third World (Ehrenreich and Hochschild, 2002). Care requirements have given rise to the so-called global chain of care (Hochschild, 2001). What is new is how this care chain is steadily increasing in the global context. The use of nannies as care providers is not a widespread phenomenon in Norway (Pettersen, 2003). On the other hand, legislation in Norway facilitates fathers to function more as care providers (Brandth and Kvande, 2001).

A nation's time regime is influenced by national production relations, national welfare politics, cultural traditions, the society's gender order (Ellingsæter, 2001) and by global processes. The connection between external global influences and responses on the local and individual level can be described as a dialectical process that links distant locations in such a way that local events are shaped by events occurring many miles away and vice versa (Giddens, 1990).

\section{THE LOCAL IN THE GLOBAL, THE GLOBAL IN THE LOCAL}

In contrast to many other countries, the Scandinavian countries ${ }^{2}$ have developed from a traditional male-breadwinner model towards dual breadwinning (Ellingsæter, 1999a). Norwegian female workers generally return to work after their maternity leave. The majority of employed mothers with one child are working full-time whereas among employed mothers with more than one child it is more common to work part-time (Kjeldstad and Nymoen, 2004). Women's total paid and unpaid work time has increased, and in dual-earner households women's total work time exceeds their male partners' (Ellingsæter, 2004). These patterns are cross-national phenomena (Fagan, 2002).

During the 1990s, the Norwegian welfare state introduced extended parental leave schemes that give parents rights and financial support to reduce their working hours and help them stay at home with their children. The parental leave consists of 52 weeks with 80 percent wage compensation, or 42 weeks with 100 percent compensation. Three weeks before and six weeks after childbirth are reserved for the mother - the 
mother quota - and four weeks are reserved for the father - the father quota. These four weeks are not transferable to the mother. The rest of the leave can be shared between the parents as they wish. The father's rights are linked to the mother's employment relations prior to the birth; the mother must have worked in a 50 percent position or more. There are also two weeks of unpaid 'daddy leave' in connection with the childbirth itself (Ellingsæter, 1999a). According to the Working Environment Act, parents have the right to extend the leave, either full leave with no pay or by going back to work part-time, for a further 52 weeks.

The Norwegian welfare state offers schemes that enable workers, female and male, to spend time with their children. It also has the aim to protect parents from the strain of working life. In doing this, the state is acting as a local 'embodying agent' in Norwegian working life and contributing to embodying both men and women as working and caring bodies (Kvande, 2005). With some exceptions (Acker, 1990; Bailyn, 1993; Fletcher, 1999; Haas and Hwang, 1995; Rapoport et al., 2002), the literature on organizations in general gives a picture of employees without gender, bodies and feelings, thereby regarding them as genderless, bodiless and insensible. Workers are treated as abstract categories where the job exists independently of the person who holds the job. Their jobs are objective categories that require an abstract worker without body and gender to do the job. A common understanding is to relate the job category to an abstract, neutral, genderless worker (read: man) who is dedicated to his job and has someone else to take care of matters within the private sphere (Scott and Morgan, 1993). Within this disembodied job a bodily process such as reproduction (Rothman, 1989) disturbs the idea of the disembodied rationality in the organization. Pregnancy is an example of a process that intrudes and disrupts the ideal functioning of the organization as a genderless and bodiless arena. Pregnancy is not only a matter of biological change with bodily effects, it is also a crucial social phenomenon (Scott and Morgan, 1993). It is common to see women as being more embodied than men (Scott and Morgan, 1993), including in the organizational context. By emphasizing gender in relation to bodily differences, the connection between gender and body or vice versa, is inevitable. Gender is something which is socially constructed. It is something we do, construct and create in social settings (Kvande, 2003). Masculinities and femininities are produced together in processes that constitute a gender order and vary with the society and the social context (Connell, 2005). The meaning of gender arises in the tensionfilled space between the local and the global.

Whether work organizations taking part in the global environment may exhibit structural convergence in their attitudes and approaches or globalization will not overwhelm, displace or reject the local features (Hannerz, 1992) depends on whether the focus is on the macro or micro level (Adler, 1986). On the macro level, organizations worldwide are growing more 
similar, while research on the micro level concludes that the behaviour of people within organizations is maintaining its cultural uniqueness. Institutional environments as socially formed norms and conventions challenge organizations as to how they should be shaped (Scott, 1992).

Work and working conditions in Norway are regulated by legislation, regulations and boundaries through the working environment and the national welfare system. Norway is at the same time integrated and dependent on international development. The consequence is pressure to deregulate working life, which can be seen to mean a high degree of time flexibility.

The globalization processes not only work out in local contexts, in which people must cope with conditions out of their control. Global processes are also simultaneously shaped, limited and redefined by sites and actors. Local practices are processes taking place within globalization processes as well as constitutive ingredients of change (Freeman, 2001). Workers gain experience in their local contexts but are also influenced by processes in the global market. A condition for studying the interplay of the global and the local is to explore workers' practices and experience in companies operating across nations and how this is affected by welfare state policies and workplace cultures.

\section{RESEARCH DESIGN AND METHOD}

This article is based on a qualitative approach. Various data sources were used as research material, including in-depth interviews, informal conversations and documents. Findings described are based on primary data: case studies carried out in two companies that are part of a global working life sector. They are both in the private high-tech industry and have a skewed distribution of gender as they are male dominated. The interviews, 13, were recorded and later transcribed.

In this article I used Mari and Sophia's stories as two pivotal cases (Mason, 2005: 196). These female workers both have experiences of taking part in the global work life during their pregnancy. Their stories illustrate how gendered dynamics have an impact on women in the contexts of global and local contexts. They are both Norwegian, in their thirties and have university master's degrees. Their stories are situated in different continents, but they both refer to the Norwegian context, where parents have a very generous parental leave system. In the following I ask what impact global and local working conditions have on female workers when they become pregnant and then later have care responsibilities and ask how this may have gendered meanings and implications for female workers. I explore the outcome of local distinctive and global processes in global work organizations. I highlight four processes during the lifecycle of female workers. 


\section{MARRIED TO WORK}

Mari's story takes place in the US, while Sophia's story is situated in Norway. Mari works in the US for an internationally reputed high-tech company. J@m consists of five companies established in different countries spread over two continents. It originally started in Norway and operates globally in 15 countries spread around the world. Their business concept is to develop and sell technology solutions. The companies are organized into projects, where each project is organized across national and continental borders. Mari's responsibility is to build alliances between technological partners and customers and look for major strategic customers. About working hours she says:

I worked approximately $45-50$ hours a week. I always checked my email in the evenings and during weekends. We used phone and video conferencing. We were sometimes up at 2, 3, 4 in the morning because we had telephone conferences with colleagues in Norway.

Projects organized across national borders imply cooperating with workers established in different time zones. The working language is English and the use of information technology gives the workers the flexibility to work at different places and at different times. Spending much time on work affects the connection Mari feels she has with her job:

It was like an intimate marriage. The expectations for your contribution were unlimited. It was not only about commitment . . . the boundaries between work and private life didn't exist.

Marriage is a formal contract where expectation and commitment are important elements. Using marriage as a way of describing commitment to a job indicates a personal, strong and close relationship between the employee and the employer.

Sophia's workplace, Seri, a high-tech company, delivers offshore installations to the oil drilling sector. It is a project-oriented company and the company operates in the global market with foreign partners and customers. Sophia is a financial manager and has tasks in all the projects. She is also indirectly connected to global working life through her husband's workplace - a Norwegian-owned company operating globally. Sophia lived and worked in Norway before she became pregnant and during her pregnancy, and relates that:

I worked between 10 to 12 hours a day. I like to work a lot. It's a positive strain.

Like Mari, she does not have a standardized pattern for a normal working week and regulated overtime. They are both in workplaces where time cultures can be labelled as boundless with long working hours and time 
norms that demand total commitment. There is no distinction between work and leisure time. These two female workers have faced the challenge of global working life by adapting to the dominant working-time culture and their behaviour contributes to neutralizing any gender. They are both dedicated workers. After some years in working life they both became pregnant. This represents a break for the female workers and in the next section I examine how their workplaces responded to this.

\section{PREGNANT AND STILL MARRIED TO WORK}

Pregnancy represents a situation where gender becomes visible. When a female worker has been pregnant for a while, co-workers usually recognize her bodily change. Norwegian legislation gives female workers the right to pregnancy leave three weeks before term, while legislation in the US gives female workers the right to maternity leave two weeks before term. During the interview Sophia told me that her colleagues, except for one, gave her pregnancy not a lot of attention:

I work with pleasant and nice men. You know, graduate engineers are usually very nice people. One of my colleagues was having his second child almost the same day I had my delivery date. He brought up the subject a lot.

She refers in her answer to graduate engineers, who are all men. They are usually nice men who never said anything disparaging about her pregnancy.

Mari's pregnancy was not mentioned at her workplace before the last day before her delivery date.

I maintained a high pace of work during my pregnancy. It was strenuous, especially at the end of the pregnancy. I was working with very demanding customers. I felt that my job and reputation depended on how things went with these clients.

Mari was on a business trip one day before the estimated delivery date. The meeting with the customers took place three hours from the nearest hospital. She had an agreement with her manager that the company would pay for a limousine if the delivery started during the trip.

There was a highly tense atmosphere at the meeting, fairly intense. Then somebody said something like 'Mari's going to have her baby if we don't calm down'. Everybody laughed and the pressure was relieved a bit, but in general the customers were still very tough, also during my pregnancy. This happened the day I left for my maternity leave. I suddenly received some comments like 'you deserve to relax'. This was the first time any of my colleagues said anything to me about my pregnancy. 
It was senior management that asked her to continue because the company needed her competence and skills. She started her maternity leave 14 days later than she should have, one day before the estimated delivery date. According to the American system, it is illegal to work during maternity leave. She negotiated a bonus payment for the period she worked after her maternity leave had started.

They sent me an email specifying the bonus payments they were going to give me and with a clear message to delete every email I had received linked to this case ... I discussed this with my husband. If I didn't do it, I think it would have had consequences for my job in the future.

She chose a strategy to avoid being squeezed out by the company. She worked a lot during her pregnancy and felt senior management forced her to continue to work after her maternity leave period had commenced.

Sophia also continued to work after her maternity leave started and received a regular salary for this period. In contrast to the American system, Norwegian legislation allows female workers to work during their maternity leave, except for the six weeks after childbirth. Neither of these female workers looks at working life as a gendered arena. By continuing to work long days during pregnancy they contribute to maintaining the idea of the organization as gender neutral. They behave like the rest of the workforce and neglected the body's need for a calmer daily life and the need for more rest. They acted as dedicated workers with strong commitment. Mari's negotiating payment for working during her maternity leave represents a break from acting as a gender-neutral worker with unlimited commitment to the workplace. A negotiated process over the maternity issue thus also took place before she went on maternity leave. This process is the issue in the next section.

\section{NEGOTIATING FOR SEPARATION FROM WORK}

The maternity leave system in the US differs from one state to the next and between companies. Where Mari lived, mothers have the right to 12 weeks' leave, whereof six weeks are covered by the state with approximately 55 percent pay. Some companies have fringe benefits where insurance policies cover up to 70-85 percent pay. The leave system in Norway is more properly referred to as a parental leave system because both the mother and father have rights.

When Mari became pregnant she applied for an extension of her maternity leave under the American system. This may be connected to her cultural background, being Norwegian she knows how the Norwegian parental leave system works and the rights her society gives to female workers. Her requirements infringed local policies and practices where 
she was located. On several occasions, she had brought up the discussion about the issues of combining work and family, but she did not expect her husband to take parental leave:

It is not that he doesn't want to be with the child, it is because he has certain expectations of how it should be. For him the existence in Norway is luxury, far away from us and not a part of our reality.

Mari explains her expectation of her husband by bringing in the interplay of her husband's nationality, the workplace policies and the role of worker in the global economy. Her husband is not a Norwegian citizen and has never been a part of a welfare state that intervenes and embodies male workers as fathers (Kvande, 2005). Her husband works in a European company that operates globally and is located in the US. The workplace time culture is boundless and family obligations are not taken into consideration. The interplay of these contexts has an impact on Mari's acceptance or rather lack of negotiation about work and family time with her husband. To be able to combine work and childcare, she negotiates with her workplace:

I had many discussions with them. They didn't have procedures for these issues. I think I was the first pregnant woman in the company so they had no experience. I had hoped to get more than the minimum, but they weren't willing to do anything about this. I also wanted them to guarantee my position in the company after my maternity leave, but they said no because I was going to take more than three months' leave. They told me they were being flexible when they allowed me to take my holidays in addition to what the legislation said.

The human resource department (HRD), located in another state than where Mari lived, did not have any procedure for dealing with maternity leave issues. She received an answer three months later. Considering her request, the HRD's answers demonstrated a lack of detailed knowledge of the working environment legislation. She had to inform them of her rights according to the law in the state she lived in. They refused to give her an extension beyond 16 weeks and to work part-time after her maternity leave. They also rejected her request for confirmation that her job position would be waiting for her after her maternity leave. The manager found it difficult to make any promises about her position such a long time into the future.

Mari had high expectations of support and demanded family-friendly policies, and said this about the answer she got from her workplace:

I felt I lost some of the deep involvement and commitment. I felt we were on different sides of the fence. I felt like it was not a reciprocal relation anymore, a feeling I had never felt before. 
She had a high sense of commitment but the influence of organizational culture, gender, sociopolitical and global context made Mari feel the employer had broken the agreement, the so-called psychological agreement (Schein, 1980). These are unwritten expectations employees have of their workplace: salary, working time, benefits and so on.

Sophia and her husband agreed that she should take most of the parental leave. This enabled her husband the opportunity to continue to work and the family to live together abroad. The Norwegian welfare state parental leave schemes gave her the rights and financial support to stay at home with their child. She did not have to go through the negotiation process. Her husband planned to take two weeks of unpaid daddy leave, a right he had as a Norwegian employee.

The negotiation process on the length of Mari's maternity leave revealed the organization as a greedy institution that occupied all her time. It is an arena where total commitment is required. The interplay of gendered dynamics between her and her husband in the family, workplace and national policy has influenced Mari's experiences. There is no space for care of the body and it is difficult to combine family and work. Mari's negotiation implies a change from being a dedicated worker with unlimited commitment to becoming a dedicated worker with limited commitment.

\section{EXCLUDING MOTHERING}

Mari's and Sophia's husbands were part of a global working life with flexible working cultures and they worked a great deal during their maternity leave period. Sophia's husband ended up working during the period he had planned to take unpaid daddy leave in connection with the childbirth. He lost his rights to stay at home with their child when he started in a new job in the same company in Europe. Sophia felt like she was a single mother.

It was hard in the beginning. I had just had my first baby and he [her husband] was away 11-12 hours a day.. Then he started to bring the work days down to 9-10 hours a day. . . . He has a job where his colleagues often call in the evenings. He often sits with the laptop in the evenings. It's like he is never off duty, even if he's on vacation ... his working time is influenced by the stock exchange in the US.

As a compensation for working during daddy leave, his Norwegian manager gave him the right to use the father's quota. The plan is to take this leave when Sophia starts work again. During her maternity leave she did some work for her company. Her working capacity when she starts to work has already become an issue: 
My manager said to me 'you're not able to work as much as you did before'. I don't think they expect me to work as much as I did before. It depends on me.

Her plan is to work less than she used to do before she had the baby. She and her husband, who still lives abroad, will hire a nanny to take care of the child when she starts working again. This will give Sophia the flexibility to sometimes work long days and travel when her work requires it.

Mari started working after four months. They hired a nanny from Norway to take care of the baby. For Mari, doing mothering includes a chain of care. Mari reduced her working hours. She expected colleagues to comment on this, but nobody said anything. She had planned to continue breast-feeding her baby, but with an open plan office she felt it was difficult. She asked her manager for permission to work at home one day a week

He was a Norwegian who knows the Norwegian culture and our attitudes to breast-feeding. I don't think it was a surprise for him that I asked. I think they would have treated an American worker the same way, but I don't think they would have asked. An American female is afraid of talking about breast-feeding because it's embarrassing.

Breast-feeding is not a taboo topic in Norway and the Working Environment Act gives mothers the right to take two hours a day off. Her manager gave her permission to work at home for a period. Mari's question reflects her cultural background and knowledge. A few months later the high-tech bubble burst - all over the world.

My manager, who was in another city in the States, didn't give me any projects. I started to look into new projects on my own. I was told that these projects had to be done by someone locally, not where I was situated. It was difficult to accept that these projects all of a sudden had to be done locally. ... This went on for three months. Then I had a meeting with my manager and I was told that I had to start looking for another job or I could get a transfer to one of the other companies. (...) When I told them I was pregnant again I got an email two hours later; I had lost my job. The possibilities of transfer were not of current interest. ... I think they would have been more creative about finding solutions if I had been a young and single man.

Employers have the power to control the projects and make decisions on who should be included or not. Mari was a female worker with care responsibilities who broke with the majority's working time practices by reducing working time and then becoming a dedicated worker with limited commitment. This in addition to a second pregnancy seems to be the explanation for excluding Mari from working life. 


\section{DISCUSSION}

In this article I have discussed what impact the interplay between workplace, the welfare state and global working life has on female workers when they become pregnant. By focusing on two highly educated Norwegian female workers, I have explored how this change process takes place in two companies operating in the global market located on different continents: Norway and the US.

The dominant working time practices at both workplaces are characterized by working beyond normal working hours and with no clear distinctions between work and leisure time. Flexible working time cultures are boundless and encourage employees to work full-time and overtime. The female workers look at the organizations as gender-neutral arenas and see themselves and colleagues as neutral workers. As long as every worker has the same work time practice - working a lot and having no obligations that interrupt the idea of the ideal worker as a dedicated worker - gender does not matter. Boundless time cultures produce workers without gender and body. The majority, men, are the carriers of the norm, and as a disembodied worker it was possible for the women to act like the majority. To indicate their strong commitment to work I have labelled this process 'married to work'.

A pregnancy represents a break and disturbs the idea of the disembodied worker in the organization as a gender-neutral area. It contributes to transforming the neutralized, bodiless female worker into an embodied worker with gender, as producer of babies and as mother with responsibilities outside the work sphere. The pregnancy may serve as a symbol for not being able to cope with the existing working time patterns. The female workers act like neutral workers by following the same norms as they used to do. They are 'pregnant and still married to work' and nobody pays any further attention to their pregnancy.

The female workers continued the same working time practices even after they were supposed to start on their maternity leave. The negotiation processes for maternity leave represent negotiations from being a dedicated worker with unlimited commitment, to being a worker with limited commitment who is able to combine work and family. Mari's story illustrates a tension-filled clash between her own demands, the workplace culture and the global and the local context. As a Norwegian, she brings with her a welfare state culture that has a generous parental leave system and different schemes that contribute to regulating working time. She encounters different conditions in the global company, a deviation that makes her negotiate for better conditions. Lewis (1996) argues that sense of entitlement is essential to translate needs into demands and bring about the changes in organizational and social structures necessary for the reconciliation of work and family. Mari's story illustrates how the 
interplay between the global and local contributes to denying employee demands for combining work and family. In her local context, illustrated by the US, the negotiation for maternity leave takes place between mother and father, and between mother, father and the workplace. It is individualized. The absence of negotiation with her husband is explained by his nationality, workplace and the workplace connection in the global market.

In Norway it is more appropriate to call the leave system a parental leave system because both mothers and fathers have individual rights. The welfare state is an actor in the discussion on time, and the negotiations take place between mother, father, company and the state. Sophia, in contrast to Mari, did not negotiate with her workplace for her parental leave. She and her husband agreed that she would take the parental leave, which gave them the opportunity to live together abroad for a period.

To be a worker in the global working world seems to set conditions that require that workers either do not have care responsibilities or at least have others to take care of their children, as long as the local policies are not considering men and women as working and caring bodies. In Norway it has become common to be both parents and employees within the parenthood sphere. According to these Norwegian employees, in global working life, global mothering appears to involve a chain of care.

Time cultures in working life organizations are formed and gain importance for inclusion and exclusion processes among the organizations' members. If pregnancy discrimination among women in global work life is widespread it means the potential recruitment of women in management in the future is low unless women do not become mothers or working fathers decrease working hours and spend more time on childcare. The third solution is that reproduction activities must be handled by others: chain of care. The female workers' experiences and negotiations represent forms of global action on local stages. We need more research to determine and generalize some of these findings.

\section{NOTES}

I would like to thank Elin Kvande for useful suggestions and comments on this article.

This project is funded by the Research Council of Norway.

1. I do not address the wider debate as to whether this is a new phenomenon, a new western curse, etc.

2. Denmark, Sweden and Norway have the highest percentage of female employees compared to other European countries (Statistics Norway, 2004). 


\section{REFERENCES}

Acker, J. (1990) 'Hierarchies, Jobs, Bodies: A Theory of Gendered Organizations', Gender and Society 4(2): 139-58.

Adler, N.J. (1986) International Dimensions of Organizational Behaviour. Boston, MA: Kent Publishing.

Adler, N.J. (1994) 'Competitive Frontiers: Women Managing across Borders', pp. 22-40 in N.J. Adler and D.N. Izraeli (eds) Competitive Frontiers: Women Managers in a Global Economy. Cambridge: Blackwell.

Andersen, L. (2003) Organisering av kunnskapsintensivt arbeid [Organization of Knowledge Work]. Trondheim: The Foundation for Scientific and Industrial Research at the Norwegian Institute of Technology (NTH).

Bailyn, L. (1993) Breaking the Mold: Women, Men and Time in the New Corporate World. New York: Free Press.

Brandth, B. and E. Kvande (2001) 'Flexible Work and Flexible Fathers', Work, Employment and Society 15(2): 251-67.

Connell, R.W. (2005) 'Globalization, Imperialism, and Masculinities', pp. 71-89 in M. Kimmel, J. Hearn and R.W. Connell (eds) Handbook of Studies on Men and Masculinities. Thousand Oaks, CA: Sage.

Ehrenreich, B. and A.R. Hochschild (2002) Global Women: Nannies, Maids and Sex Workers in the New Economy. New York: Henry Holt.

Ellingsæter, A.L. (1999a) 'Dual Breadwinners between State and Market', in R. Crompton (ed.) Restructuring Gender Relations and Employment: The Decline of the Male Breadwinner. Oxford: Oxford University Press.

Ellingsæter, A.L. (1999b) 'Time and the Transformation of Work: The Industrial Time Regime in Flux', pp. 25-47 in G. Birkelund (ed.) Kjønn og arbeid - Nye normer for arbeidsliv, Konferanserapport del 1. Oslo: The Research Council of Norway (RCN).

Ellingsæter, A.L. (2001) 'Tidsregimer under omforming' [Time Regimes Undergoing Change], Tidsskift for Samfunnsforskning 42(2): 347-72.

Ellingsæter, A.L. (2004) 'Tidskrise i familien?' [Time Crisis in the Family?], pp. 128-59 in A.L. Ellingsæter and A. Leira (eds) Velferdsstaten og familien. Oslo: Gyldendal.

Epstein, C.F., C. Seron, B. Oglensky and R. Saute (1999) The Part-Time Paradox: Time Norms, Professional Lives, Family and Gender. New York: Routledge.

Fagen, C. (2002) 'How Many Hours? Work-Time Regimes and Preferences in European Countries', in G. Crow and S. Heath (eds) Social Conceptions of Time, Structure and Process in Work and Everyday Life. London: Palgrave.

Fletcher, J.K. (1999) Disappearing Acts: Gender, Power, and Relational Practice at Work. Cambridge, MA: The MIT Press.

Freeman, C. (2001) 'Is Local:Global as Feminine:Masculine? Rethinking the Gender of Globalization', Journal of Women in Cultures and Society 26(4): 1007-38.

Giddens, A. (1990) The Consequences of Modernity. Cambridge: Polity Press.

Golden, L. and D.M. Figart (2000) Working Time: International Trends, Theory, and Policy Perspectives. London: Routledge.

Haas, L. and P. Hwang (1995) 'Company Cultures and Men's Usage of Family Leave Benefits in Sweden', Family Relations 44(1): 28-37.

Hannerz, U. (1996) Transnational Connections: Culture, People, Places. London: Routledge.

Hewitt, P. (1993) About Time: The Revolution in Work and Family Life. London: Rivers Oram Press. 
Hirst, P. and G. Thompson (1996) Globalization in Question: The International Economy and the Possibilities of Governance. Cambridge: Polity Press.

Hochschild, A.R. (2001) 'Globale omsorgskjeder' [Global Chain of Care], Kvinneforskning 2: 5-13.

Hochschild, A.R. (2002) 'Love and Gold', pp. 15-30 in B. Ehrenreich and A.R. Hochschild (eds) Global Women: Nannies, Maids and Sex Workers in the New Economy. New York: Henry Holt.

Kearney, M. (1995) 'The Local and the Global: The Anthropology of Globalization and Transnationalism', Annual Review of Anthropology 24: 547-656.

Kjeldstad, R. and E.H. Nymoen (2004) Kvinner og menn $i$ deltidsarbeid: fordeling og forklaringer [Women and Men as Part-Time Worker: Distribution and Explanation]. Oslo: Statistics Norway.

Kvande, E. (2003) 'Doing Gender in Organizations: Theoretical Possibilities and Limitations', pp. 15-44 in E.S. Gunnarsson, A. Andersson, A.L. Rosell and M.S. Karlsson (eds) Where Have All the Structures Gone? Stockholm: Centre for Women's Studies.

Kvande, E. (2005) 'Embodying Male Workers as Fathers in a Flexible Working Life', pp. 75-89 in D. Morgan, B. Brandth and E. Kvande (eds) Gender, Body and Work. London: Ashgate.

Lewis, S. (1996) 'Sense of Entitlement, Family Friendly Policies and Gender', pp. 17-42 in H. Holt and I. Thaulow (eds) Reconciling Work and Family Life: An International Perspective on the Role of Companies. Copenhagen: The Danish National Institute of Social Research.

Mason, J. (2005) Qualitative Researching. London, Thousand Oaks, CA and New Delhi: Sage.

Mitter, S. and S. Rowbotham, eds (1995) Women Encounter Technology: Changing Patterns of Employment in the Third World. London: Routledge.

Pettersen, S.V. (2003) Barnefamiliers tilsynsordninger, yrkesdeltakelse og bruk av kontantstøtte våren 2002 [Families with Children Supervision-Arrangements, Labour Force Participation and Use of Cash for Care, Spring 2002]. Oslo: SSB.

Rapoport, R., L. Bailyn, J.K. Fletcher and B. Pruitt (2002) Beyond Work-Family Balance: Advancing Gender Equity and Workplace Performance. San Francisco: Jossey-Bass.

Rothman, B.K. (1989) Recreating Motherhood: Ideology and Technology in a Patriarchal Society. New York: Norton.

Sassen, S. (2000) 'Women's Burden: Counter-Geographies of Globalization and the Feminization of Survival', Journal of International Affairs 2: 53.

Sassen, S. (2002) 'Global Cities and Survival Circuits', pp. 254-74 in B. Ehrenreich and A.R. Hochschild (eds) Global Women: Nannies, Maids and Sex Workers in the New Economy. New York: Henry Holt.

Schein, E. (1980) Organizational Psychology. Englewood Cliffs, NJ: Prentice-Hall, Inc.

Scott, S. and D. Morgan (1993) 'Bodies in a Social Landscape', in S. Scott and D. Morgan (eds) Body Matters: Essays on the Sociology of the Body. London: Falmer Press.

Scott, W.R. (1992) Organizations: Rational, Natural and Open Systems. Englewood Cliffs, NJ: Prentice-Hall.

Sennett, R. (1998) The Corrosion of Character: The Personal Consequences of the Work in the New Capitalism. London: W.W. Norton.

Statistics Norway (2004) 'High Labour Force Participation among Women in Nordic Countries'; at: www.ssb.no/samfunnsspeilet/utg/200401/03/

Wajcman, J. (1999) Managing like a Man: Women and Men in Corporate Management. Sydney: Allen and Unwin. 
Hege Eggen Børve is research fellow in sociology at the Norwegian University of Science and Technology in Trondheim, Norway, and associate professor at Nord-Trondelag University College, Levanger, Norway. Her fields of interest include work and organization with an emphasis on gender. She is currently working on a project called 'Globalization and Flexible Working Time Cultures', a project connected to the research programme 'Flexible Working Time Cultures and Parents' Time Conflict'. Address: Norwegian University of Science and Technology, N-7491 Trondheim, Norway. [email: Hege.Borve@svt.ntnu.no; Hege.borve@hint.no] 